\title{
Total Harmonic Distortion of Single Phase Mid-Point Cycloconverter Comparison Between MOSFET, IGBT and GTO Power Devices
}

\author{
Ammar Falah Algamluoli \\ Assistant Lecturer at University of Baghdad \\ Collage of Engineering
}

\begin{abstract}
Power Electronic Cycloconverter circuits use in different application for example, ship propulsion and cement mill. These applications require adjustable speed to do their job. Changing number of pole of motor is quite difficult. So, Cycloconverter circuit play important role to adjustable speed higher or lower than synchronous speed. In this paper, single phase mid-point Cycloconverter will be investigated. MOSFET, IGBT and GTO will be used as power devices in Cycloconverter circuit. Harmonics and total harmonics distortion(THD) for Cycloconverter circuit will be compared between these power devices. Pulse width modulation technique PWM will be used as gate drive for all power devices. MATLAB software will be used in this project.
\end{abstract}

\section{Keywords}

Cycloconverter, MOSFET, IGBT, GTO, Harmonics and THD

\section{INTRODUCTION}

Several application use cycloconverter circuit for example cement mill drives, ship propulsion, HVDC transmission systems and Aircraft or shipboard power supplies Mine winders [1],[2],[3]. When, number of poles in induction motor are changed, motor speed will change. However, these method is not technical [4]. So, Cycloconverter power electronic circuit involve in this field in changing supply frequency. It works to change the fixed input frequency into higher or lower than input frequency which depend on required application. However, there is huge harmonics in output of power converter. These harmonics effect on the power system network. Which cause distortion in voltage and current waveform [2],[8]. So, in this paper will be focused on harmonics and THD comparison between MOSFET, IGBT and GTO as power devices in single phase mid-point Cycloconverter power electronic circuits. In addition, which of these power devices will be more suitable in Cycloconverter circuit in step up and step dawn frequency.

\section{LITERATURE REVIEW}

Several studies have been carried out in cycloconveter circuit. According to [1], Staircase modulation technique has been used in Single Phase Matrix Converter as gate drive. The result was reduced THD in output where IGBT power device was used in [1]. In [2], the author carried out simulation of single phase to single phase step dawn cycloconverter fed single phase induction motor. The number of various speed in induction motor after changing input frequency into low frequencies $F / 2$ and F/3 have been carried out in [2]. The comparison between MOSFET and IGBT power devices in single phase to single phase step dawn Cycloconverter only has been made in [3]. Author's results that THD was low about $0.02 \%$ in IGBT in comparison with MOSFET power device. However, PWM has not been used in [3] as gate drive circuit. In addition, two cases in step dawn frequency have been investigated in [3], which consider first weakness in [3] Furthermore, step up frequency have not been mentioned in [3], which consider the second weakness in [3]. In [4], single phase to single phase Cycloconverter FED Split Phase Induction Motor has been simulated in MATLAB. IGBT power devices has been used in [4] . the results that Speed control of induction motor after changing output frequency was made. Furthermore, the effect of changing frequency output on machine torque was investigated in [4]. According to [5], carried out simulation of single phase mid-point cycloconverter in matlab Simulink. Variation of output frequency in step up and step dawn frequency in circuit was made in [5]. MOSFET power devices was used in[5]. In [7], single phase to single phase with Trapezoidal modulation technique has implemented instead of PWM technique. Where, the fundamental output voltage in cycloconverter was increased about $15 \%$ after using trapezoidal technique. In addition, the harmonics in circuit have been reduced. The reduction in THD of cycloconverter circuit was about 1 to $2.5 \%$. these percentage was for frequency range between 1 to $16.66 \mathrm{HZ}$ [7].

\section{CIRCUIT OPERATION}

To understand the operation of the single phase mid-point Cycloconverter, with $200 \mathrm{~V}$ input ac voltage from source and $50 \mathrm{HZ}$ frequency input. It has single phase transformer with taping in secondary side in order to get two waveforms with phase shift 180 degree. The simulation circuit is shown in fig 1 and output waveform is shown in Fig. 2.

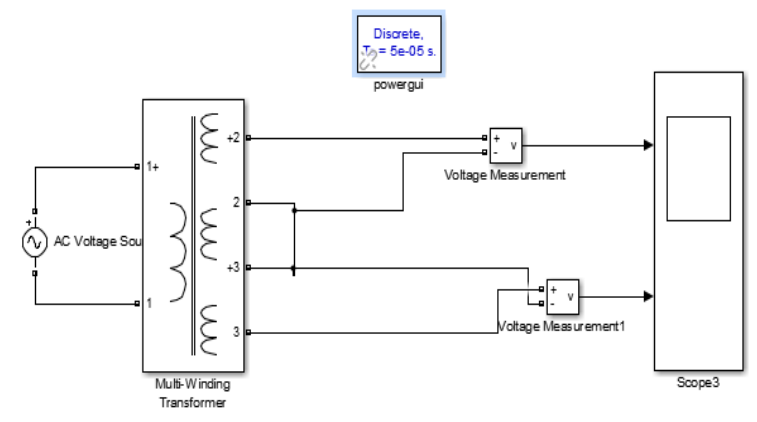

Fig. 1 - single phase mid-point cycloconverter 


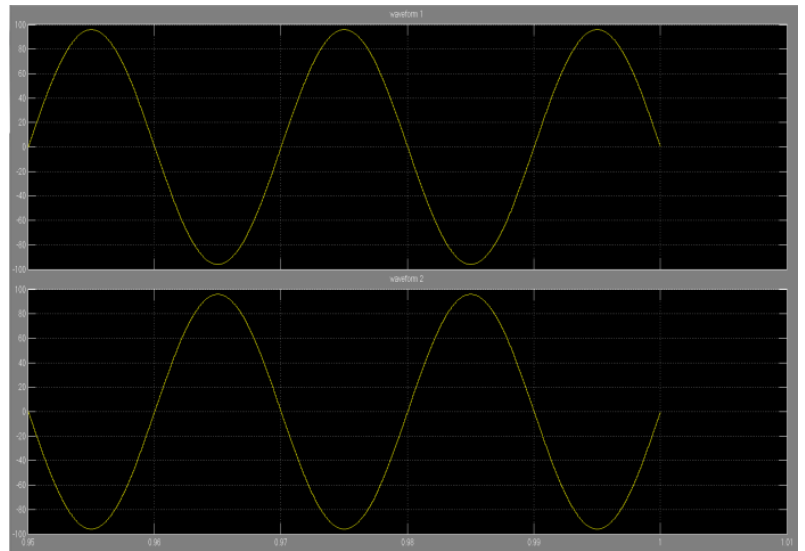

Fig. 2 - output waveform of secondary side taping transformer.

From Fig. 2 Waveform 1 are connected to group of power devices one of them is positive (P1) and the other one is negative(N1). Waveform 2 are connected to group of power devices as well negative (N2) and the second one positive (P2). The final circuit with power devices are shown below in fig 3. output waveform of this circuit is explained in detail in discussion and results parts.

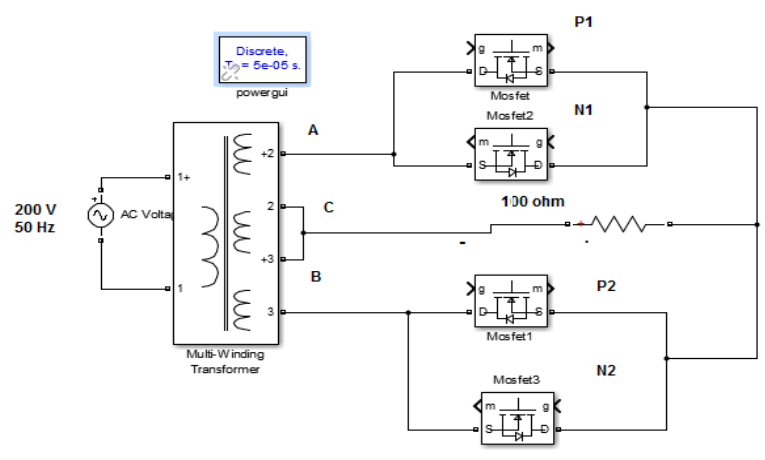

Fig. 3 - Single phase mid-point Cycloconverter circuit with power devices as (+ve group P1 and P2, -ve group N1 and N2).

\section{METHODOLOGY}

Single phase mid-point cycloconverter power electronic circuit are simulated in MATLAB Simulink. Firstly, MOSFET power devices with internal Diode on parallel is connected in circuit in order to check the harmonics and THD of the output waveform. MOSFET specifications are Ron resistance $0.2 \mathrm{ohm}$, rd diode resistance $0.8 \mathrm{ohm}$ and with diode forward voltage equal to $4 \mathrm{~V}$. Secondly, IGBT power devices is connected instead of MOSFET power devices to check the THD and Harmonics of the output waveform of the circuit. IGBT specifications are Ron resistance $0.2 \mathrm{ohm}$. Same as with GTO power devices, where Ron resistance is $0.2 \mathrm{ohm}$. Supply Input voltage is $200 \mathrm{~V}$ peak amplitude with frequency input equal to 50HZ. PWM pulse width modulation is used as gate drive for all three types of power devices with modulation indx is equal to 0.5 .

\section{MODELLING OF PWM GATE DRIVE}

In this project, PWM as gate drive is used. So, the Simulink block and waveforms of PWM, control signal A, control Signal B and gate pulse for each -ve and +ve group power devices are shown below in Fig. 4and Fig 5.

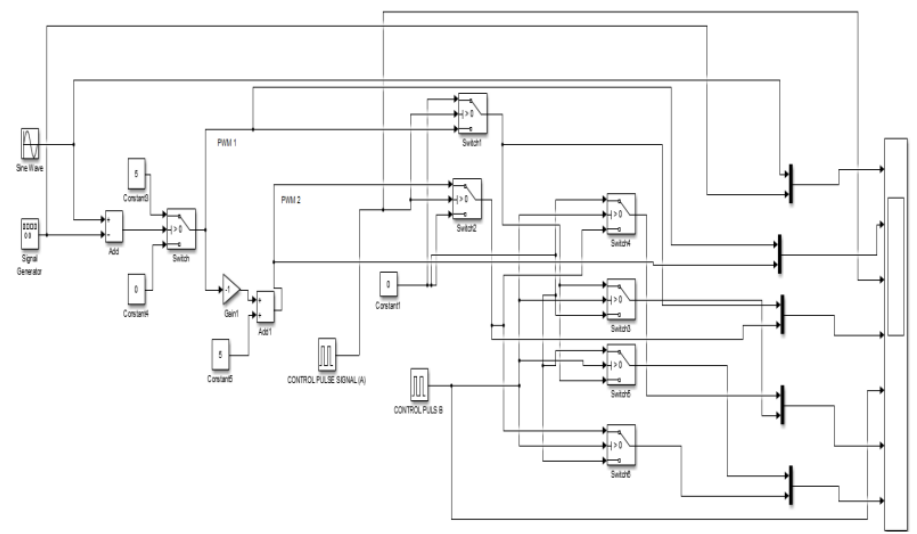

Fig. 4 - Simulink Blocks of PWM gate pulses of power devices.

From Fig 4 above, module of PWM blocks is simulated in MATLAB Simulink. The blocks module consists sine wave signal with $5 \mathrm{~V}, 50 \mathrm{HZ}$ and sawtooth carrier signal with $10 \mathrm{~V}$ and $5 \mathrm{KHZ}$ as shown in Fig 5.

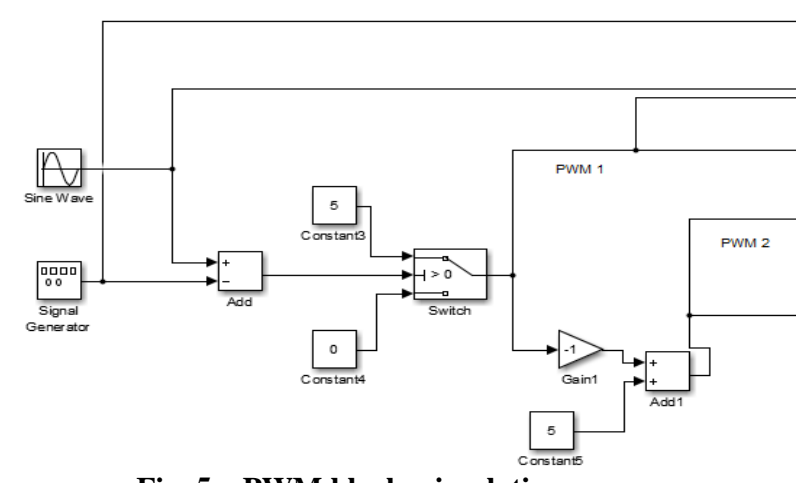

Fig. 5 - PWM blocks simulation

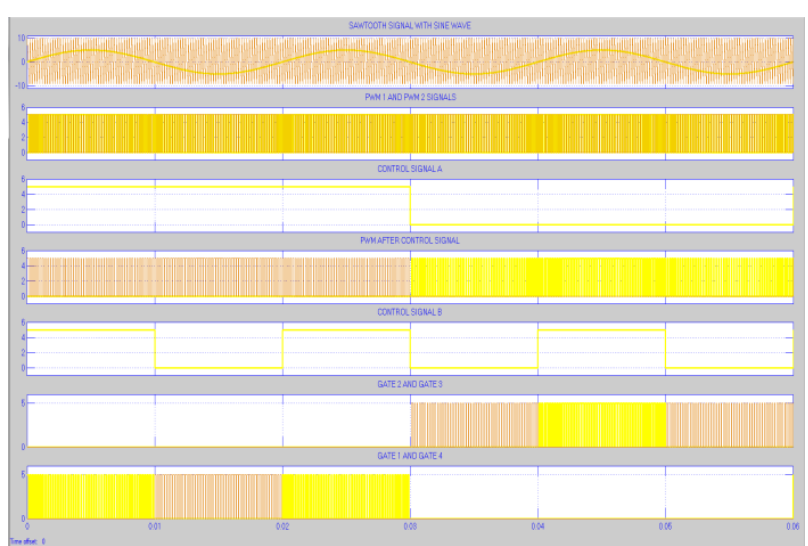

Fig. 6 - PWM signals with control signal (A), Control signal (B) and gate pulse for each -ve and +ve group power devices when getting output frequency is $F / 3$. 


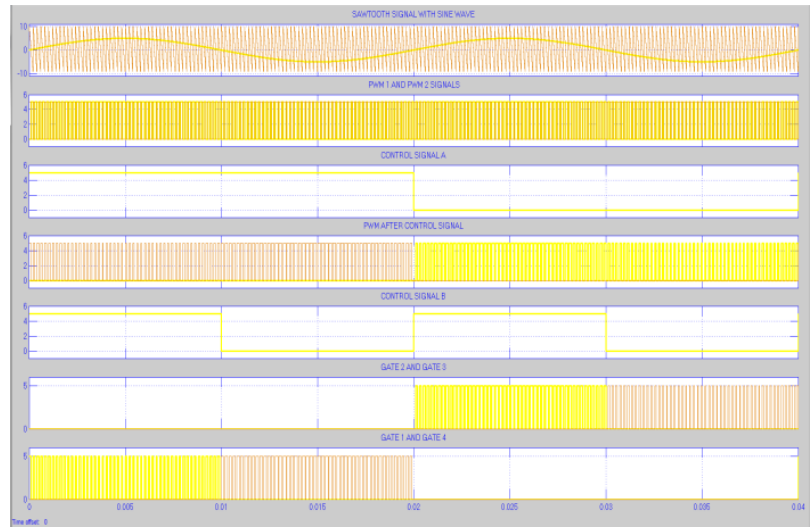

Fig. 7 - PWM signals with control signal (A), Control signal (B) and gate pulse for each -ve and +ve group power devices when getting output frequency is $F / 2$.

From Fig 6 and 7 above, the output frequency of Cycloconverter is changed by changing the period of control signal (A). For example, to get step dawn frequency $F / 3$ in output of cycloconverter, this is mean output frequency equal to $16.666 \mathrm{HZ}$, If the supply frequency is $50 \mathrm{HZ}$. This is equal in time $0.06 \mathrm{sec}$. So, the period of control signal (A) must change to $0.06 \mathrm{sec}$ as shown above in fig 6 . While, to get $\mathrm{F} / 2$ half of supply frequency, the period of control signal (A) must be changed into $0.04 \mathrm{sec}$.

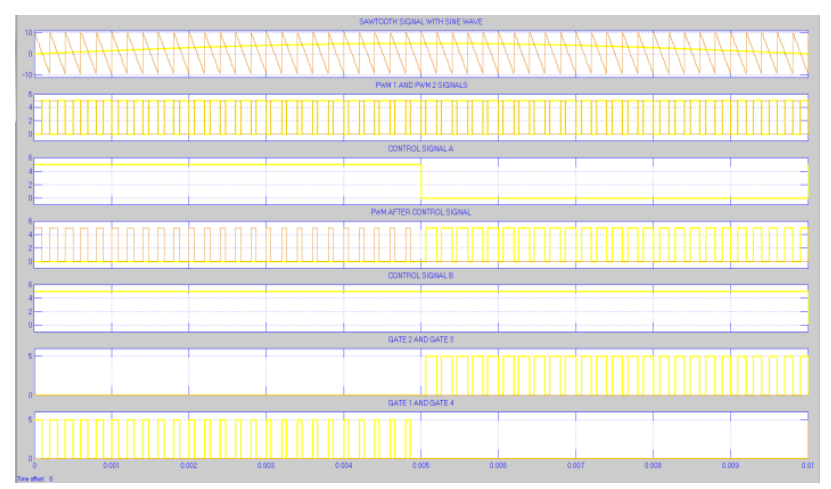

Fig. 8 - PWM signals with control signal(A), Control signal (B) and gate pulse for each -ve and +ve group power devices when getting output frequency is $2 \mathrm{~F}$.

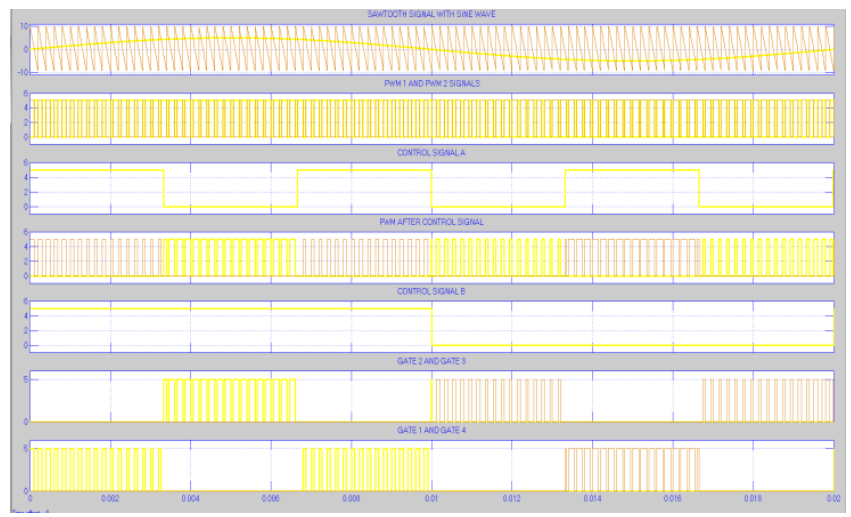

Fig. 9- PWM signals with control signal(A), Control signal (B) and gate pulse for each -ve and +ve group power devices when getting output frequency is $3 \mathrm{~F}$.

From Fig. 8 and 9 above, to get step up frequency $2 \mathrm{~F}$ in output of cycloconverter, this is mean output frequency equal to $100 \mathrm{HZ}$. This is equal in time $0.01 \mathrm{sec}$. So, the period of control signal (A) must be changed to $0.01 \mathrm{sec}$. as shown above in fig 8 . While, in order to get $3 \mathrm{~F}$, the period of control signal (A) must be changed into $0.0066667 \mathrm{sec}$.

\section{RESULTS AND DISCUSSION}

Harmonics and THD will be investi gated for Single phase mid- point Cycloconverter circuit in this paper. The comparison will be made between three power devices which are MOSFET, IGBT and GTO as power switching devices in cycloconverter circuit. The Simulink of cyclocnveter circuit with power devices is shown in figures below:

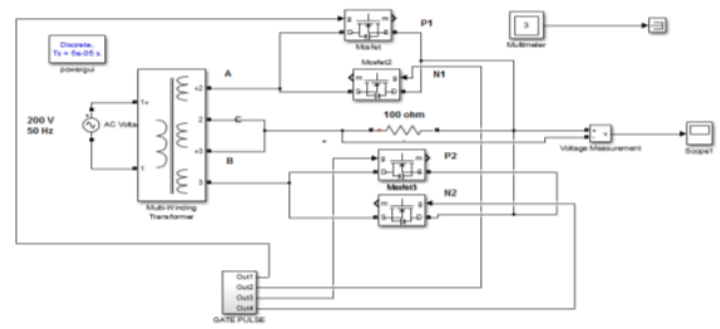

Fig. 10 - Simulink block of cycloconverter single phase with MOSFET power devices

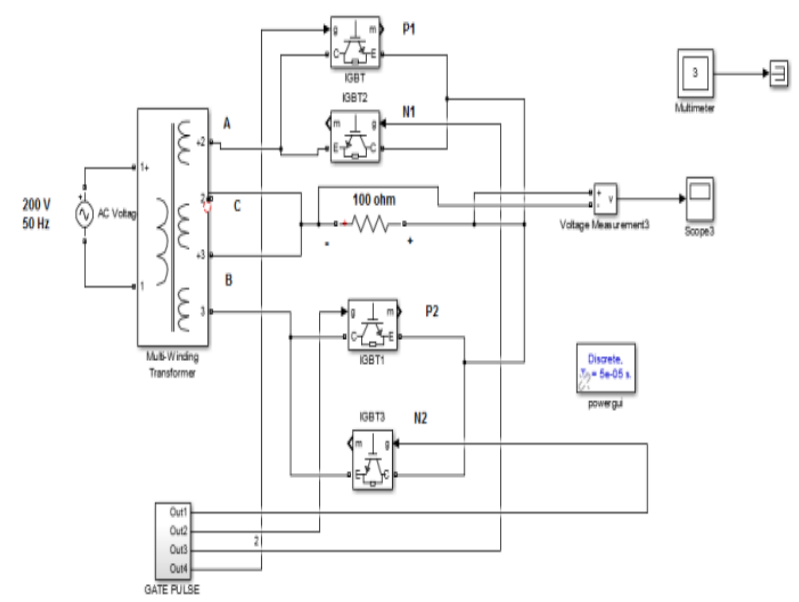

Fig. 11 - Simulink block of cycloconverter single phase with IGBT power devices

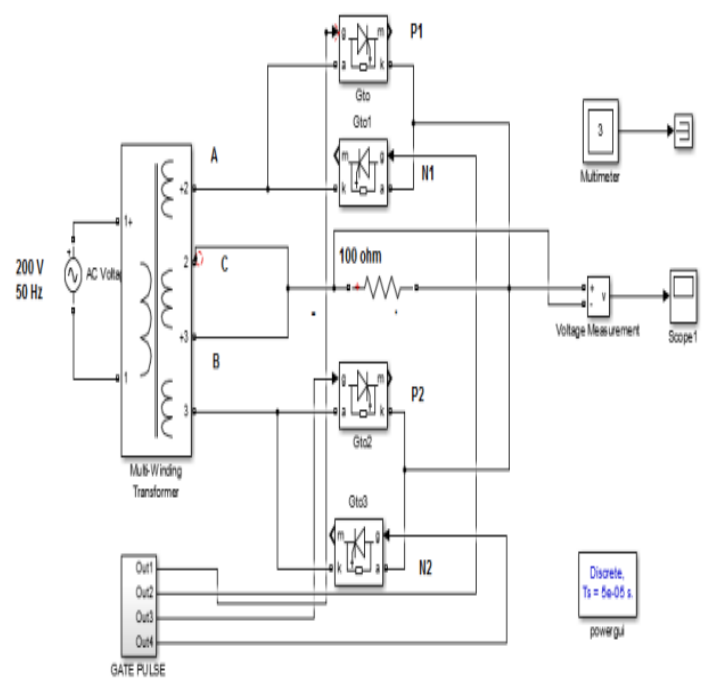

Fig. 12 - Simulink block of cycloconverter single phase with GTO power devices 


\subsection{Results of Step dawn Cycloconverter Circuit}

The output waveform and harmonics of Cycloconverter in step dawn frequency for three types of power devices are shown below:

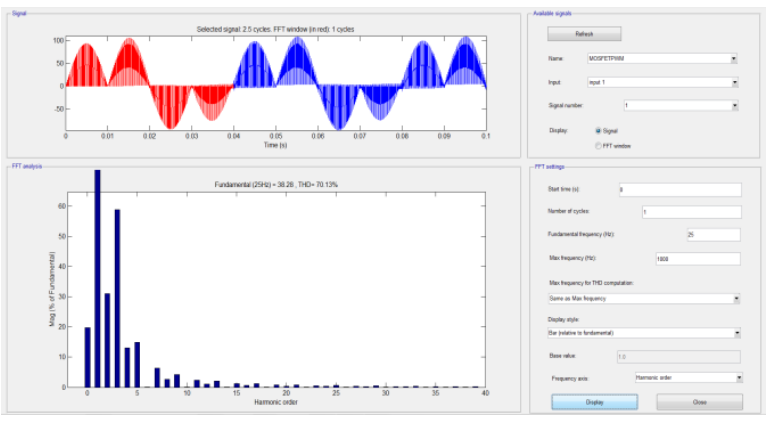

Fig. 13 - output waveform, harmonics and THD of F/2 output frequency of Cycloconverter when MOSFET power devices.

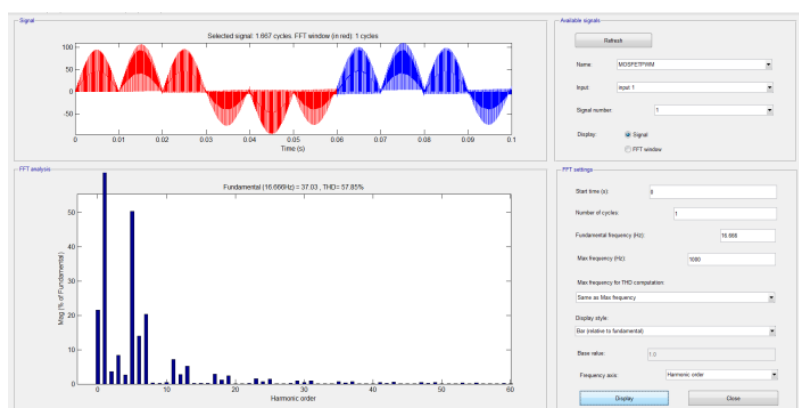

Fig. 14 - output waveform, harmonics and THD of F/3 output frequency of Cycloconverter when MOSFET as power devices.

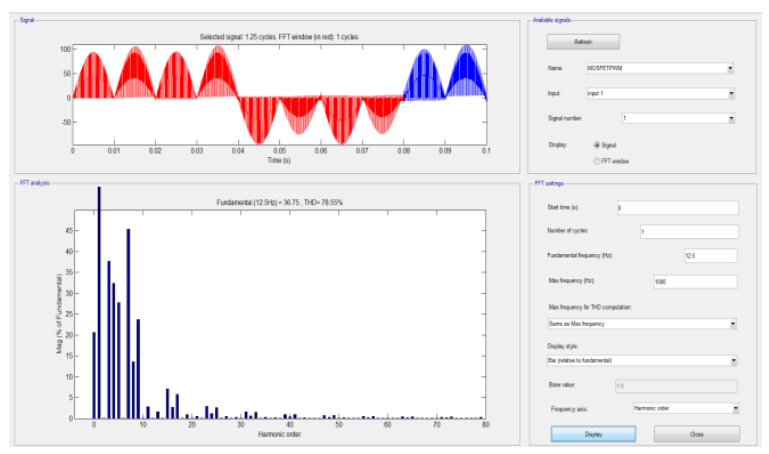

Fig. 15 - output waveform, harmonics and THD of F/4 output frequency of Cycloconverter when MOSFET as power devices.

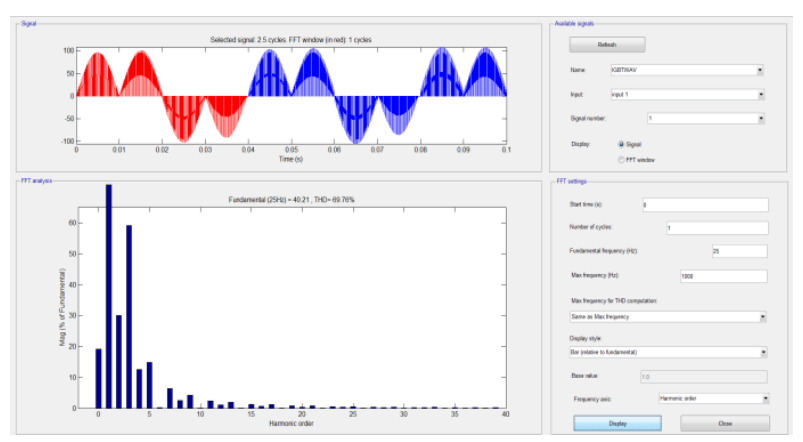

Fig. 16- output waveform, harmonics and THD of F/2 output frequency of Cycloconverter when IGBT as power devices.

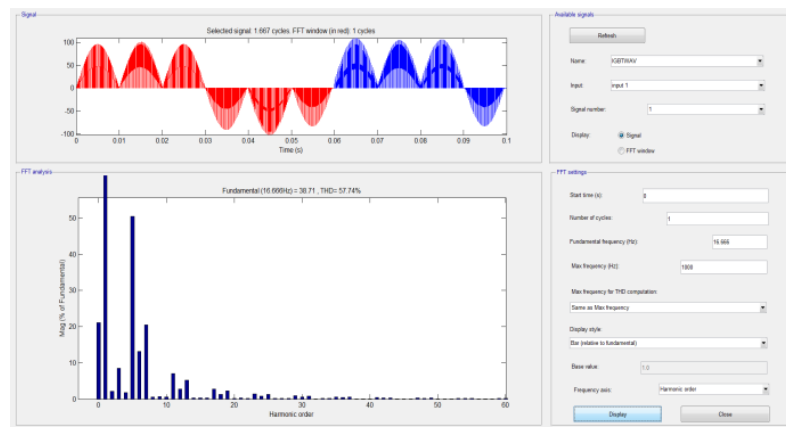

Fig. 17 - output waveform, harmonics and THD of F/3 output frequency of Cycloconverter when IGBT as power devices.

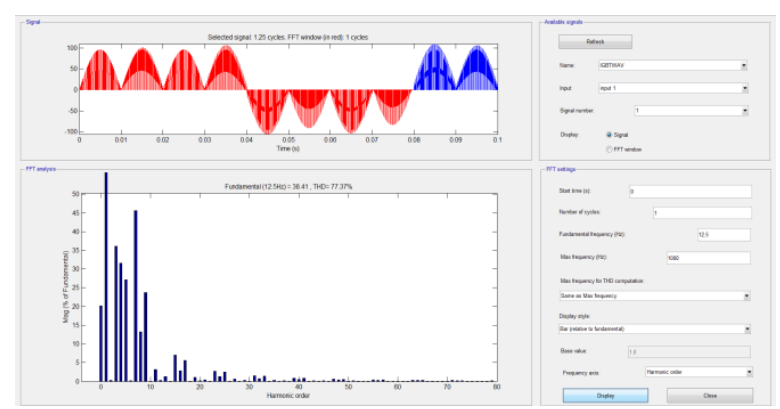

Fig. 18 - output waveform, harmonics and THD of F/4 output frequency of Cycloconverter when IGBT as power devices.

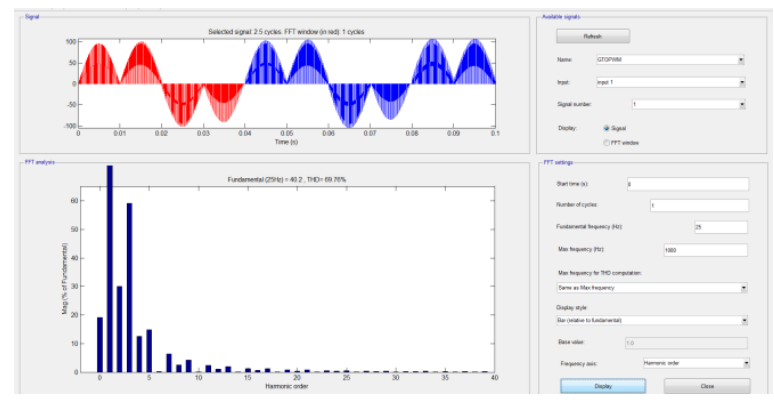

Fig. 19 - output waveform, harmonics and THD of F/2 output frequency of Cycloconverter when GTO as power devices.

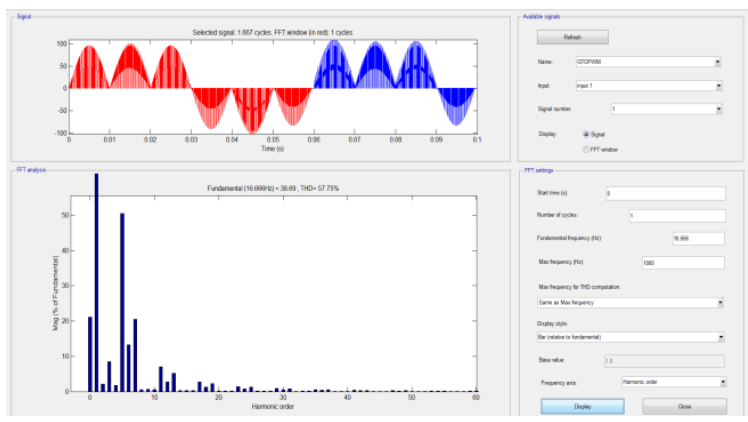

Fig. 20 - output waveform, harmonics and THD of F/3 output frequency of Cycloconverter when GTO as power devices. 


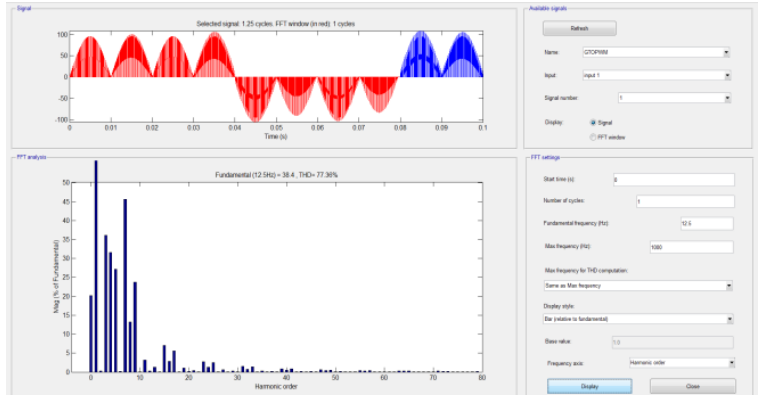

Fig. 21 - output waveform, harmonics and THD of F/4 output frequency of Cycloconverter when GTO as power devices.

Table 1 THD of output step dawn single phase mid-point Cycloconverter circuit for three types of switching power devices.

\begin{tabular}{|c|c|c|c|c|}
\hline $\begin{array}{c}\text { Power } \\
\text { Devices }\end{array}$ & $\begin{array}{c}\text { THD } \\
\text { at F/2 }\end{array}$ & $\begin{array}{c}\text { THD } \\
\text { at F/3 }\end{array}$ & $\begin{array}{c}\text { THD } \\
\text { at F/4 }\end{array}$ & $\begin{array}{c}\text { THD at } \\
\text { F/5 }\end{array}$ \\
\hline MOSFET & $70.13 \%$ & $57.85 \%$ & $78.55 \%$ & $69 \%$ \\
\hline IGBT & $69.76 \%$ & $57.74 \%$ & $77.37 \%$ & $69.42 \%$ \\
\hline GTO & $69.76 \%$ & $57.75 \%$ & $77.36 \%$ & $70.05 \%$ \\
\hline
\end{tabular}

From Table 1 above, It can be seen that the more suitable power devices for step dawn single phase mid-point cyccloconverter circuit are IGBT and GTO power devices. Where, THD of Cycloconverter circuit when IGBT or GTO as switching power devices are lower than the THD when MOSFET as switching power devices. Also, the percentage of THD of circuit when IGBT and GTO power devices are almost equal. However, THD of output frequency F/5 of cycloconverter circuit when MOSFET power devices are connected is lower than THD when IGBT and GTO are connected as switching power devices as shown in Table $\mathbf{1}$.

While, in [3] only step dawn frequency has carried out and the result of the comparison between IGBT and MOSFET was IGBT more suitable in step dawn cycloconveter circuit. However, in this project, the result of comparison between IGBT, MOSFET and GTO are investigated. Where, GTO and IGBT power devices are more fitting in step dawn single phase Cycloconverter.

\subsection{Results of Step up Cycloconverter Circuit}

The output waveform and harmonics of Cycloconverter in step up frequency for three types of power devices are shown below:

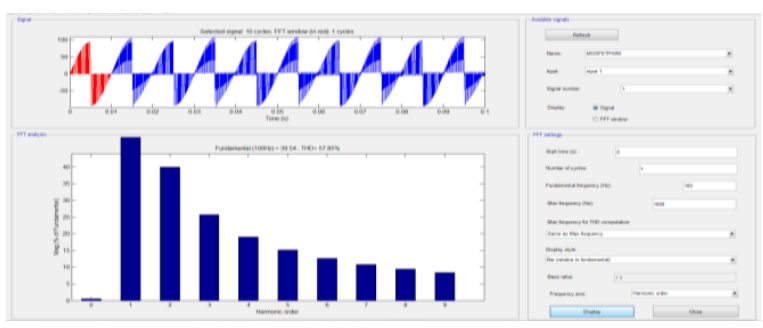

Fig. 22 - output waveform, harmonics and THD of $2 \mathrm{~F}$ output frequency of Cycloconverter when MOSFET as power devices.

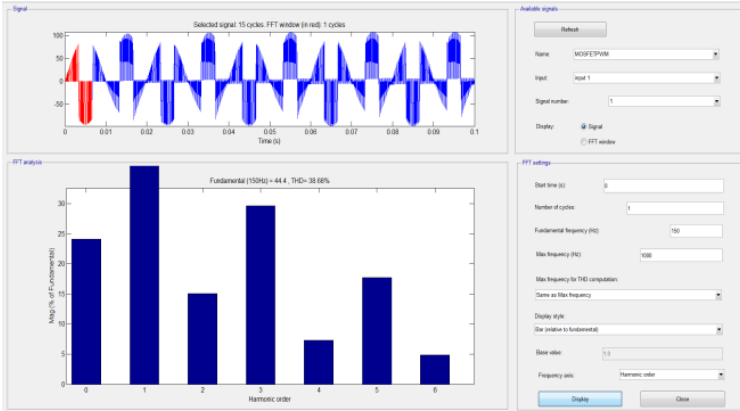

Fig. 23 - output waveform, harmonics and THD of 3F output frequency of Cycloconverter when MOSFET as power devices.

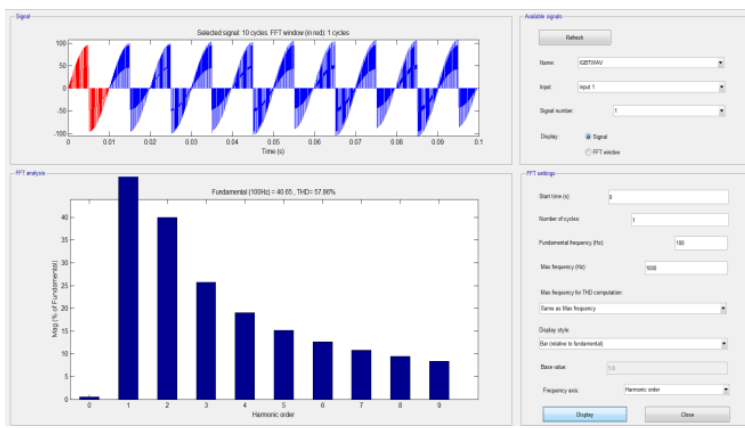

Fig. 24 - output waveform, harmonics and THD of $2 \mathrm{~F}$ output frequency of Cycloconverter when IGBT as power devices.

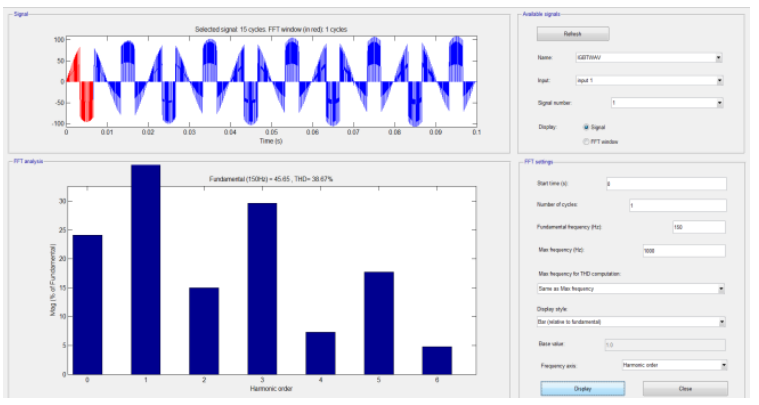

Fig. 25 - output waveform, harmonics and THD of 3F output frequency of Cycloconverter when IGBT as power devices.

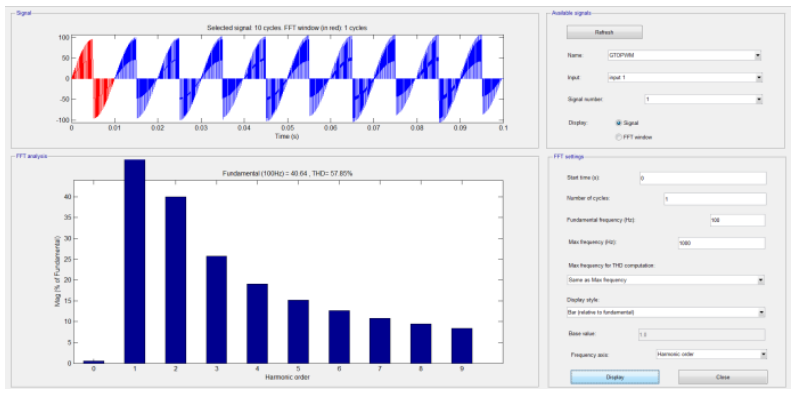

Fig. 26 - output waveform, harmonics and THD of $2 F$ output frequency of Cycloconverter when GTO as power devices. 


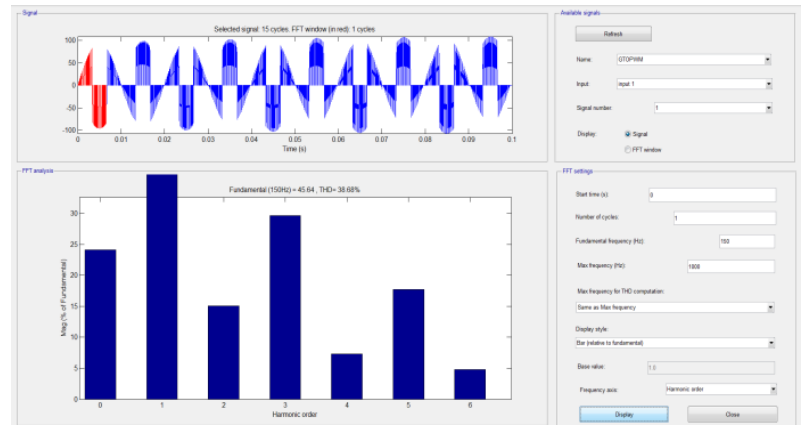

Fig. 27 - output waveform, harmonics and THD of $3 F$ output frequency of Cycloconverter when GTO as power devices.

Table 2 THD of output step up single phase mid-point Cycloconverter circuit for three types of switching power devices.

\begin{tabular}{|c|c|c|c|c|}
\hline $\begin{array}{c}\text { Power } \\
\text { Devices }\end{array}$ & $\begin{array}{c}\text { THD at } \\
2 \mathrm{~F}\end{array}$ & $\begin{array}{c}\text { THD at } \\
3 \mathrm{~F}\end{array}$ & $\begin{array}{c}\text { THD at } \\
4 \mathrm{~F}\end{array}$ & $\begin{array}{c}\text { THD at } \\
5 \mathrm{~F}\end{array}$ \\
\hline MOSFET & $57.85 \%$ & $38.68 \%$ & $36.66 \%$ & $31.75 \%$ \\
\hline IGBT & $57.86 \%$ & $38.67 \%$ & $36.66 \%$ & $31.74 \%$ \\
\hline GTO & $57.85 \%$ & $38.68 \%$ & $36.64 \%$ & $31.74 \%$ \\
\hline
\end{tabular}

From Table 2 above, It can be seen all power devices are tested in this project are the best for step up single phase midpoint Cycloconverter circuit. They have same THD of all output frequency of Cycloconverter circuit.

\section{CONCLUSION}

As a result, the simulation of single phase mid-point cycloconverter has been made in MATLAB Simulink. Simulink block of PWM gate drive for switching power devices in circuit has been designed. Three types of power devices have been used in this paper. Also, circuit simulation with MOSFET, IGBT and GTO power devices have been made. THD of output waveform of cycloconverter for three switching devices has been compared. The researcher findings that the best power devices for simulated Cycloconverter circuit when, output frequency is $\mathrm{F} / 2, \mathrm{~F} / 3, \mathrm{~F} / 4$ and $\mathrm{F} / 5$ are GTO and IGBT power device. While, MOSFET, IGBT and GTO are the best power devices in step up single phase midpoint cycloconverter circuit. Where. They have same THD of output waveform of simulated circuit in all output frequency [9]
$2 \mathrm{~F}, 3 \mathrm{~F}, 4 \mathrm{~F}$ and $5 \mathrm{~F}$. After using IGBT or GTO as power devices step dawn in simulated circuit. THD will be reduced, where the less harmonics will pass in power system components.

\section{REFERENCES}

[1] Biswas, A., Jaiswal, J. L., \& Agarwal, V. (2012, December). A study of staircase modulation technique for single phase matrix converter. In Power, Control and Embedded Systems (ICPCES), 2012 2nd International Conference on (pp. 1-6). IEEE.

[2] Epemu, A. M., \& Enalume, K. O. (2018). Speed Control of a Single Phase Induction Motor Using Step-down Cycloconverter. International Journal of Industrial and Manufacturing Systems Engineering, 3(1), 6 .

[3] Vinodhini, J. S., Babu, R. S. R., \& Glenn, J. A. (2016, March). Single phase to single phase step-down cycloconverter for electric traction applications. In Electrical, Electronics, and Optimization Techniques (ICEEOT), International Conference on (pp. 4914-3647) IEEE.

[4] Govil, V. K., \& Chaurasia, Y. (2012). Modeling \& Simulation of PWM Controlled Cycloconverter FED Split Phase Induction Motor. international journal of advanced research in Electrical, Electronics and Instrumentation Engineering, 1(3).

[5] Narayanan, M. (2016). MATLAB Simulation of Single Phase Mid-Point Step Up and Step Down Cycloconverter. International Journal of Scientific Research in Computer Science, Engineering and Information Technology (IJSRCSEIT), 1(2), 18-21.

[6] Agarwal, V., \& Agarwal, P. (2008). IGBT based cycloinverter. Asian Power Electronics Journal, 2(1), 55-59.

[7] Agarwal, A., \& Agarwal, V. (2009, December). Harmonic reduction in $\mathrm{AC}$ to $\mathrm{AC}$ converter by trapezoidal modulation technique. In Power Systems, 2009. ICPS'09. International Conference on (pp. 1-6).

[8] Ramsden, V. S., Hunter, G. P., \& Zhang, J. (1995). Impact on the power system of single-phase input cycloconvertor motor drives. IEE Proceedings-Electric Power Applications, 142(3), 176-182. 